\title{
SP INTERVIEW WITH FREDRIK BARTH
}

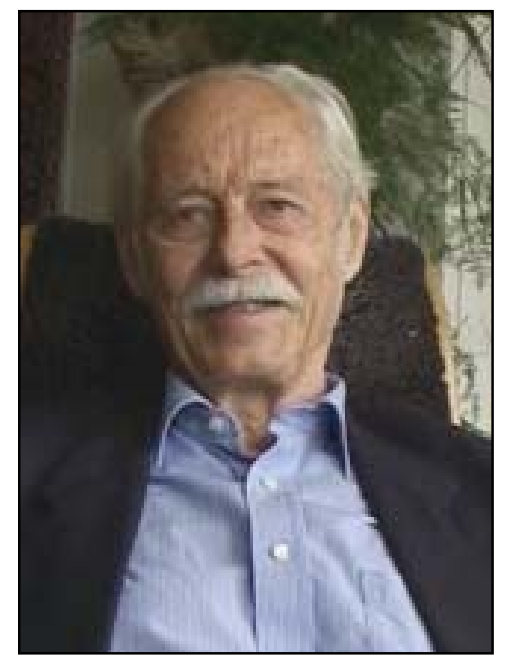

Interviewer's note: while a visiting fellow at Cambridge University in 2004-2005, and working towards a study of the biographical origins of Political Systems of Highland Burma, I spoke with a number of people about their memories of Edmund Leach. This led to an approach to Frederick Barth, asking his agreement to allow me to video a conversation with him, to be part of the series on anthropological ancestors coordinated by Alan Macfarlane at Cambridge. Using an inexpensive direct flight to Oslo from an airport near Cambridge, I finally mounted the tram which winds up the side of the mountains overlooking Oslo, and, on a brilliant sunny morning, entered the house he has lived in since 1961. Professor Barth, then aged 77 , had just returned from examining a dissertation at the University of Bergen. The trees and gardens around it resembled our own in Vancouver, and the tram continued higher toward the famous Holmenkollen ski jump. The house is decorated with carpets and objects collected by Professor Barth, skilfully combined with beautiful and useful Norwegian things. We sat in a room which overlooks a sheer drop 300 meters to a lake below, all within the boundary of the city. Afterwards he courteously carried me down to the city in his car, on his errand, showing that he was as much a skier as a driver. We had, therefore, conversations which do not appear in this transcript here. I record my gratitude to him for his generosity of spirit toward an absolute outsider.

R.A. It is a great honour and pleasure finally to meet you. We can ramble in the conversation and for those that have a more linear interest, we can later reconstruct it and...

F.B. Cut and paste...

...cut and paste, yes. So what was it, as you approached your undergraduate studies, that drew you towards anthropology?

Yes...let's see. As a boy I was interested in zoology like many boys are, and I discovered evolution, and I discovered palaeontology and that's really my childhood or boyhood orientation. Then, my father was a geochemist and he was asked shortly after the end of the war to be a visiting professor in Chicago, so I just finished my high school, or whatever you would call it, and I went along with him. That is how I got into the University of Chicago and started with palaeontology and anthropology, thinking about human evolution and then very quickly on the course of a couple of years sort of moved through the spectrum of American anthropology, and then I ended up at the social end of it. 


\section{This would be in what year?}

Nineteen forty-six to forty nine.

And in that movement along that spectrum from human evolution to palaeontology to anthropology, can you remember any particular people who were like "sign posts" or "guides"?

Well...Chicago was a marvellous place then. It was doubly marvellous because it was the period of the Gl's, so the students were mature and highly motivated, I guess they are still motivated but no so mature and so I was with a crowd of very fine people. And the faculty was doing its best. I guess the people that I had most directly to do where I started on the palaeontology and archaeology was Bob Braidwood, and it was Bob Braidwood who took me to the Middle East. I had some competence in, you know, physical anthropology and osteology of animals, and so I tagged along as his "bone man."

Braidwood was a real hybrid, working in the frontier of bones and palaeontology but also with a keen interest in eventually large civilizational questions.

Yes, but at that time it was...the beginnings of agriculture, so I was his man on that wing, so...

\section{And had Redfield come to Chicago by that time?}

Redfield was there and he was the chair of the department, but he was a rather distanced figure, and since I was not a humanist but a "scientist," I was never close to him. But he was very influential on everybody's thinking. And Sol Tax was at that time an unimportant person, so all his organizing energy went into the department. And he was fun, he was a very, very funny man. And Lloyd Warner was there, and the sociologists. Erving Goffman was more or less my contemporary, so I knew him and I got a great stimulus from his book The Presentation of Self in Everyday Life.

That suggests a nice mix of sociology, anthropology and history. 
Yes, history in the sense of evolution, but also Braidwood's cultural history. And all of them suited me very well. I could, I think, have been happily continued in either one of these areas.

At some point there must have been a decision for you to go into graduate studies in anthropology, and then do fieldwork?

Yes, I took it for granted all the time that I would go into graduate studies. But that it would end up being social anthropology depended very much on my... well, I guess there were several components, but my pleasure at seeing tribal people and discovering how accessible they are and the enjoyment of working with living people, so I sort of took off on there.

\section{And where did that first experience take place?}

That was all in Iraq on Braidwood's Jarmo excavations... when it would have been? 1951 maybe...

\section{Were there other students along? Was it a kind of team?}

Yes, Adams...Bob Adams. He was one of my fellow students, there were two or three more, but I only had a few months there with them in Iraq, and then they left and I stayed on.

Were you at all drawn up towards the mountains, towards the Kurdish area? Yes.

Were you aware at that moment that Edmund Leach had done fieldwork in 1938 in that Kurdish speaking area?

No, I was not and of course he wasn't known to anyone, he was a very sort of an unrecognised figure at Chicago at that time. So...l came back to Norway but here there was nothing for me. I was looking for a place to do a doctorate and I thought I could write it and submit it here...

Here, in Oslo?

Yes.

\section{Not at Bergen?}


No. At Bergen there was not... it was hardly a University at that time. So I thought about what I had learnt in Chicago and I decided that I wanted to study with Raymond Firth in London. In 1951 or1952, I got a small pot of money here for a year in England, and I went to the LSE. And when studies toward the degree were arranged, Firth wrote me a letter and he said he would be away and out of there for half the time, but they had teaching there Edmund Leach, who had been in Kurdistan. So, what could be better than that? And I was terribly disappointed because I was sure that Raymond Firth would be much better than anyone else, [better] than some Englishman who had been...you know. But anyway, it was exiting to go to London and there were many people there, and then I met Edmund Leach and I think it took two hours and I fell in love. He had that kind of intellectual force and that strength. I admired him very much and I got to love him very much.

It was not long before Leach moved to Cambridge. Was the decision taken that he would supervise your dissertation or that it would be Firth who would do it when he came back?

It was Edmund who did it... only, as far as they were concerned it was a manuscript, it was not a dissertation and...

\section{You had written it here?}

I was in the process of writing and sort of finishing. And after my year there in London I came back and I submitted it, and I was young and rushed, and it wasn't the best piece of work I've done, and they failed me for the doctorate.

\section{The LSE did?}

No, Oslo did.

I see, so you were in a sort of ...

A study year abroad.

So you expected to come home and present it here. Yes...

And these examinations here, I understand there is a big public element... 
Yes, a public defence

\section{Can you describe how that is done?}

Well I'd never got to the defence because they simply... I now have an understanding of what was going on, but the "official one" was simply that they sought advice from abroad because this was a new field and so on. And there were members of my committee who would be my competitors if l'd got the degree, and they asked Evans-Pritchard in consultation [about the dissertation]. And they got a five line sort of "letter" back, containing really very little other than saying that the absolute requirement in Oxford was more than a year of fieldwork and I didn't have that. So I wouldn't have received their degree in Oxford. And that's all they said. So of course we [Oslo] want to be as good as Oxford, so I couldn't receive the degree here either! And it was after that, that I managed to get a five years stipend. Some members of the faculty thought that there was something to me and my work, and I got a new chance, and then I went to Pakistan to work with the Swat.

Did you transfer some of the model that you had built in the first manuscript to the Swat situation?

I did so, yes. The first manuscript was clearly dependent on a Weberian kind of approach to politics and I think it that's been with me all my life. But at that time I went to the field, and that is when Edmund moved to Cambridge and I didn't want to submit it again here, so then I arranged to do my doctorate in Cambridge.

\section{And he was the person who was identified as the supervisor?}

Yes, and he was very welcoming and all of Cambridge was welcoming, an extremely fine intellectual experience...

\section{A fine time to be there? Was it like being at Chicago at that earlier time?}

Yes.

You were very lucky in your timing. Were there many people who you can remember who came this way, so to speak, from Chicago or from Harvard or New York, towards Cambridge, in the way you did?

Oh, yeah, there was quite a bit of that. Many of my fellow students from Chicago, in fact, turned out to be there in the UK. Elisabeth Bott, she was at the L.S.E and 
remained there, at the Tavistock Institute for a long time, and was also a very close friend of Edmund. And Tom Fallers was in Oxford and... there must have been a couple of others... so I felt almost as if I was part of this very small wave of Chicago anthropologists going to England.

\section{So you came back from life with the Pathans.}

Yes, that must have been in 1954, when I did that fieldwork.

We can hardly imagine anyone living among the Pathans without being changed somewhat by them. What kind of effect did this fieldwork experience have on you this time?

Yes, indeed! I confirmed my sense, and it may have exaggerated my sense that political life is struggle and that many people are fighting for advantage, and that this dynamic comes about through thinking strategically. So I feel that the analytical perspective that I used for the study of Swat Pathans was... yes, it was attractive to me in terms of this intellectual argument, but that is also what people in Swat taught me.

So they themselves have an awareness that this is what political life is?

Right. They have a very harsh awareness, that this is a real struggle for survival.

\section{And you can loose?}

You can loose terribly... yes, and nobody will look after you. You can have friends if you can contribute something mutually, but you can't be a free rider anywhere. Descent gives you certain cards to play but you have to play them...

\section{And are there better players and poorer players?}

Yes.

And on the way down, so to speak, can one see how the way up looks? And on the way down, are you saying that there is no cushion underneath you?

None. 
This work was done at the time when Political Systems of Highland Burma was published. Did the book influence you, or was it too late to influence you much?

It was more the influence of Edmund's reasoning. It has always influenced me since. I mean, it is a marvellous book and it carries so many ideas and stimuli for thinking, so the book certainly has influenced me. But for the Pathan work it was Leach's presence and thinking that mattered, not the manuscript. But of course this was while he was writing the Burma book, so he was full of it.

So, there you were in Cambridge, writing your dissertation, in a very lively milieu?

Yes, it was a small group, actually, but they were very interesting people. Particularly Jean La Fontaine, also the Canadian Bill Dunning, who is not very well known.

He was one of my teachers at the University of British Columbia Is that so? He was a very fine man...

Yes, very gentle, very observant...

Nur Yalman came for my second year, he had been in the field and came back, and of course he was a major element in that environment.

At that stage did you think of staying in Cambridge? What were your thoughts about what steps you would take next?

No, I was rather dedicated to a sort of a double commitment to bringing anthropology to Norway, and to myself living in Norway, being a Norwegian, so this was collecting ideas and strengths so that I could do things here.

We are sitting in a house which you bought in 1961 but we are not far from the house in which you grew up. So in a sense you are a very local man, here.

Yes. It's a combination that I value for my own enjoyment, being very locally rooted and being cosmopolitan.

And have you been able to encourage others to follow this anthropological path? 
Yes, indeed. And my 10-12 years in Bergen was a combination of that, because it was a new university and they sort of chose me and gave me the support that I needed.

\section{Did your father stay on in Chicago?}

No, he spent many of his young years abroad because there wasn't much possibility here. It is a very small country here and at that time a very poor country really, and so you didn't have much career opportunity. So he spent a number of years in Germany, where I was born and then he had five years or something like that in America, in Washington DC, in a research institute there, and then we were here for my childhood and during the war. And then he would spend some years in Chicago, and get back here again. I guess I simply agreed with him on that kind of pattern, that you participate in the world but this is where you want to be.

\section{What kind of influence did your mother have on your thinking or on your way of doing things?}

My mother was a lower-middle class person with great sense of humour and gaiety, and she married this young promising academic. They were very close. Whereas he was so shy, rather like Edmund Leach: a powerful intellect with this sort of emotional shyness. My mother was much more exuberant and giving, and so I think I got some of my social skills from her more than from him.

\section{Do you have siblings?}

I have an older sister, who was... we were very close as children because we lived for some years abroad, but not intellectually of importance for me, we are sister and brother like friends.

So you completed your dissertation and then you translated it into a book...

Yes, I think it was published in 1959 , as I got the Cambridge degree in $1957 \ldots$

\section{And then you came home to Oslo.}

Yes, I came home in 1957, directly after completing the degree.

Was the climate more receptive? 
Well, they couldn't stop me anymore but it wasn't at all that receptive, no. So I had some years living by yearly stipends and what I could pick up. Columbia University in New York invited me for a year's visiting professorship, which was my first international break in 1961, something like that. And all this added up to a reputation here, so that then Bergen then asked me to come to work there.

\section{And that would be when?}

Maybe in 1962.

\section{So you really stepped out of Oslo and built something at Bergen?} Yes.

\section{And was it possible to go back for fieldwork or for visits to the Pathans or anywhere else during this pre-Bergen period?}

Yes. It would have been possible. I did go back. Robert Pehrson, an American anthropologist who had worked with the Lapps and I became acquainted, and we decided before, around 1953-1954, that we would work together with this sort of ecology and politics perspective and he chose to go to Baluchistan. But he died in the field. So I was given his material by his wife, his widow, and I used it as a lure to get some money to go back to Pakistan, with the Wenner-Gren Foundation, which has been very supportive toward me and very important for me. They gave me the money so I could go to Baluchistan and see the place and that allowed me to revisit Swat. It was 1961, 1962, something like that.

\section{Did the Pathans and the Baluch have any ongoing relationship?}

Well, again I was pursued by luck because the Baluch that Bob Pearson worked with are bilingual in Pashto and Baluchi. So I could just walk in. And they interpreted my sentimental journey to the place where he died as representing brotherhood. So the memory of him among them was the key that opened the place to me.

And to them that's highly valued, that a person would follow there to honour him?

Right. So I was very happy to be able to write a monograph on the basis of his material. But I don't recommend it to anyone else! No, it is a very demanding thing to track. 
This ecology and politics model is something Leach's dissertation anticipates-this is in 1947- and he anticipated how that should be done, and Political Systems of Highland Burma does it. Would you say that what Raymond Firth wanted to create is what we now call "economic anthropology," in which his thinking, your thinking worked through this relationship of ecology and politics?

Yes, very correct, very much so. And obviously since he was articulating this, I was very influenced by him then. But again it suited me so nicely, because I had the biological background that he didn't. So I knew what ecology was, and in a sense could think of it in a more restricted and professional sense.

Yes, I remember Leach being critical of what he called "the biological analogy." I guess he felt more comfortable with structures, and stresses, and forces, being an engineer. What then becomes of that model of thinking during the sixties?

It was not very well used in the discipline, I think. It was used as a platform for making competing claims for where the "real truth" was, whereas to me, it has always been fundamentally in my fieldwork, always. This is really the way I frame local life. And to my way of thinking it's so uncontroversial, there is no alternative to it. But for me, it has surely estranged me from the more rigorous structuralist kind of perspective. Because you take something that is fortuitous and complex and dynamic, and they turn it into something relatively static, and intellectualized, and oversimplified.

Do they oversimplify because they want to identify only what they think are the fundamentals?

Yes, what they think are the fundamentals. Its because their idea of generalization and fundamentals is an ideational one, instead of being one of processes, biological constraints of ecology.

A minute ago, you used the word "fortuitous": are you saying that "probabilities" are always at work?

This was the strong sense that I have. Look at this landscape, I mean, all the trees that fortuitously... the seeds have dropped there, then they aggregate together and create a situation, that yes, you can characterize it by abstract structural things, but it hasn't been generated by those abstractions. It has been generated by elemental 
processes where each event is pretty fortuitous. That fascinates me; I think its much more fun than to abstract until you have something that is intellectually clean and exaggerated.

\section{And less able to handle contingency?}

Yes, and much less able therefore to handle time and change.

There's a phrase used in one of your early books which l'd like to ask you about: "A season is a stretch of country."

Yes, yes. That's in the Nomads...

Yes, in The Basseri, "A season is a stretch of country".

Put yourself in the subjectivism of acting people, and what do they have to go by, for their experience? And they reason over it, and they know that that stretch of country is always there, but that's sort of irrelevant for them, because they come through that bit of country in the beginning of May, and that's what is important. And so I did get a sense being with them that their subjective construction was very much in this combination of movement, and place, and time. And they have their idea of usage rights for pastures, for example, it's quite explicitly one of place and time.

\section{Yes, the place being unambiguous, but the time being perhaps negotiable.}

Yes, and that's what nomadic superstructure of politics is. Having your chief, who can negotiate with other chiefs of other tribes while using the same channel but in a staggered way. And my image for it, which I think is very close to their way of thinking, is the time schedule of a train. The train has to be somewhere, but it's not interested in owning a place, it's interested in working out a time schedule, so there's always a place where it's supposed to be.

\section{Did your reading of Durkheim or anyone else lead you to that view of time and space?}

No, it didn't. I can say that quite explicitly because, when I discovered Durkheim and Mauss, working with these ideas, I thought "how fascinating," and then I went and read them, and I was disappointed, because they couldn't add anything to what I had already reasoned. 
At some point your work became described as "transactionalism." Did you coin that phrase?

I can't have, it must have been around. I was simply looking for a way to conceptualise the systematicity that people impose on their fortuitous relationships, that was the idea. If I could find such a thing, then I would be on to something that I could use in processual terms.

\section{Looking back in Leach's Political Systems, do you see that idea there?}

Yes its there, but I don't think he exploits that as fully as he could.

I'm not sure that he was explicit about fortuitousness as much as you are.

No, right. Because he was an engineer, the workings of the system didn't contain anything fortuitous. It was like a design.

But did he see the stresses? There was a design, but there were forces and tensions, I guess, so things weren't always coherent?

Yes, but he saw that as a disturbance, rather than as...the moving power.

What, in retrospect, do you think of this phrase, "transactionalism?"

Well, it clearly has invited people to pick up the wrong part, it's not clearly enough conceptualised and argued. And I hear, I've always heard these objections, that it's so instrumental, and it's so opportunistic, and it's so immoral to have that kind of image of mankind. And that wasn't my point. My point was that we see reciprocities, and that's sort of a mild term, but it's a fuzzier way of saying the same thing. And I think that most of our basic relationships, all of our basic relationships, are social relations that are built around mutual transactions. And there's no way you can escape it, because unless you look to the accounting of it, your social and economic assets will be dissipated. So you have to [face it], there's nothing immoral about it, it's not trying to make the most out of your grip on others. It's trying, on the contrary, to create a satisfactory life, a rich mutual life together.

Where your expectations and the expectations of others are in some kind of reciprocal frame?

Right. And we construct that frame through the experience of successful transactions with each others. 
To use another language, that is how trust is built, if it is built at all.

Yes, exactly.

The process you've just described might ideally have been the Oslo process between the Palestinians and the Israelis?

Right.

The life of the Pathans and Baluch has been terribly troubled, and so what do you think has happened to their own way of making conflict within this bigger militarized context?

I hope that they are experiencing that they have to find ways of limiting and dampening this intensity of confrontation, because their normal way of responding is escalation, and that has been obviously, very destructive in their lives. I don't know, I would have to go there and listen to the kind of discourse that they are engaging, and I don't have the materials... but it looks as if they are pretty unchanged, from the outside. I was thinking seriously of going back, maybe 10 years ago or something, but quite frankly I'm afraid of these anti-personnel mines. When I do fieldwork I wonder all over the place, and I don't want just to follow the tracks that they have cleared. And many of them have indeed lost their lives, yes, many of them.

At some point you move your attention from the edge of Afghanistan to the Pacific. And that's quite a journey! Can you describe how that came about, and what sort of different approaches were in your mind then?

Well, first, whenever I was thinking towards future fieldwork, I put the question to myself, where will I learn most by going? And it seemed always to me that, apart from some brief visits, perhaps, I would always learn most by going to a new place, where everything would be new, where I didn't know it before, and so I have that sort of spirit of adventure, justifying it in terms of what it would bring me as a basis for anthropological insight. That's one component. The other was that I had said, I'd held some important things about political processes, about ecology, about economics in that sense, and I had not focused on the analysis of ritual, meaning, and everybody else in anthropology was talking about that, so I wanted to be with them, and join them. And my idea then was to get a primary body of materials, so I could join in the general arguments and analysing the meaning of these. And I combined that with a 
sense of adventure, and a curiosity that l'd always had about "untouched" New Guinea, and I chose this area which was still untouched and less spectacular than the proper Highlands, and a more modest kind of way of life.

\section{Modest meaning less theatrical?}

Yes, and smaller scale. But they were so recently contacted that it was this sort of naïve dream of the untouched place, I can't free myself from the sense, that it is an anthropological treat. But what I wanted to do was to look in detail at ritual. And in a sense, try to do for ritual what I had done for politics, see how it is built, how it is constructed as a verb, rather than as a structural sort of noun.

So I had the surprise of collecting a few myths that, indeed, were very LéviStraussian, so I recognized that there must be something going on like that. But most of my interest was focused on the imagery of ritual. And so where do these idioms or images, get their meaning from and what are they used for, so my whole idea was to analyse the Baktamen and their cultural imagery for its substantive content of cosmology.

\section{So time and space again?}

Yes, but experienced time and space, not conceptualized time and space.

Now, in the Nomads book you describe the Basseri as having a "poverty" of ritual.

Yes.

And in the Highlands of New Guinea might you be tempted to say that they have an abundance, even a superabundance of ritual?

Yes, I would.

Where would you place the Baktamen people that you worked among in New Guinea in this spectrum, in this kind of distinction you are making between poverty and abundance?

There is no abundance because indeed they are too poor and too elementary to have abundance. But what they do create of ritual imagery and visions I found very moving, perhaps precisely because of that, because they are humble people, and clearly they were trying and wanting to make something, and my sense was that 
what I was seeing was a systematic struggle to try to construct a way of understanding that's related to mystery, rather than to intellect and science or order, or classification and so on. And that's really when I finally got to the point of seeing that.

If they were humble, in this sense, did they express any surprise to you that a person like you would be interested in their cosmology or in their experience?

No, they were too unsophisticated to have any such sense.

So they took as natural that a person would come and ask them?

Yes... a male getting older among them wants to know these things.

And you were what age at that point, Fredrik?

Let's see... I was forty.

Yes, and building a department at Bergen with colleagues?

It was a year away, yes, in 1968, while the intellectual world was transformed.

Did you look for a politics in the ritual structure, carrying on from your earlier work? Reputation in ritual, perhaps?

Yes, I looked for it but I think it's empirically correct that it is not a significant factor. They have no ideology of equality, but in fact they are pretty cruel. And the kind of influence, control, and... knowledge and secrecy is such a fickle thing... so since they can't control physical resources it's really very difficult to build any kind of position of power through that.

\section{So, specialist and specialization, not being handed on in a generational way?}

Well, there is handing on, but the emphasis, as I saw it, is that always came back to the same thing that it's secret, and then it becomes powerful. And it was a monkey wrench in political scheming because yes, you can hint that there are things that you guys don't know, so many times, but it doesn't sort of take you anywhere.

And was it a more peaceful environment? I take it that for the Pathan and the Baluch, their world is at moments pretty tough and conflictual?

Yes among them it was explicitly and knowingly conflictual and it was sophisticated in terms of strategic reasoning. That is not the case in the area in New Guinea were I 
was. It was violent. They were fighting all the time. I did life stories, siblings groups, all the counting that I could, and it seems that about more than a third of deaths were caused by physical violence in the total population, not just among warriors, but woman and children, and everybody. So in that sense it was conflictual, but in terms of...well, without a view of strategy.

Pretty unusual to find a people without a view of strategy. Was this a departure for you, then?

Yes, indeed, it was.

Did you have to set aside an assumption that everybody has a life of strategy, not to unreasonably impose it onto this people?

Well, my expectation was to find something different, to be surprised. So I wasn't trying to press it into a model. But I was noting that it never came out that way, it came out another way, and that fascinated me. I remember the only explicit piece of strategy that I ever heard was from one of my good friends, who spoke to me. I was wanting one of the highest initiation ceremonies to take place while I was there, so I could see it and be included in it. And I was pushing for that, and the fully initiated people recognized that this was what I was doing, and one day they said to me "Don't worry about the chief priest, the important man is actually that one over there."! So it is not that strategy is a foreign way of thinking, but it has very limited relevance to their life.

\section{Have you gone back recently to that part of New Guinea?}

Not recently, l'd got an opportunity to go back 12 years after field work, something like that, when they found gold in the area and were developing the mine. And that was immensely interesting, but I haven't come back since. You know, the world is too big. I learn more by going somewhere else.

But don't you have an historic grounding which would allow you to measure what has become of those parts of Pakistan and New Guinea?

Right, so maybe I am chasing naïve thrills than rather maybe going places that I know about. Yes. I think that can be argued that I would learn more by going [again] to a couple of those places. 